OPEN ACCESS

Edited by:

Massimo Broggini,

Mario Negri Pharmacological

Research Institute (IRCCS), Italy

Reviewed by:

Joshua Mincer,

Memorial Sloan Kettering Cancer

Center, United States

Angela Santoni,

Sapienza University of Rome, Italy

*Correspondence:

Marie-Odile Parat

m.parat@uq.edu.au

Specialty section:

This article was submitted to

Cancer Molecular Targets and Therapeutics,

a section of the journal

Frontiers in Oncology

Received: 11 October 2021 Accepted: 06 December 2021 Published: 23 December 2021

Citation:

Scroope CA, Singleton Z, Hollmann MW and Parat M-O (2021) Opioid Receptor-Mediated and Non-Opioid Receptor-Mediated

Roles of Opioids in Tumour Growth and Metastasis.

Front. Oncol. 11:792290. doi: 10.3389/fonc.2021.792290

\section{Opioid Receptor-Mediated and Non-Opioid Receptor-Mediated Roles of Opioids in Tumour Growth and Metastasis}

\author{
Claudia A. Scroope ${ }^{1}$, Zane Singleton ${ }^{1}$, Markus W. Hollmann ${ }^{2}$ and Marie-Odile Parat ${ }^{1 *}$ \\ 1 School of Pharmacy, The University of Queensland, St Lucia, QLD, Australia, ${ }^{2}$ Department of Anaesthesiology, Amsterdam \\ University Medical Center, Academic Medical Center (AMC), Amsterdam, Netherlands
}

Opioids are administered to cancer patients in the period surrounding tumour excision, and in the management of cancer-associated pain. The effects of opioids on tumour growth and metastasis, and their consequences on disease outcome, continue to be the object of polarised, discrepant literature. It is becoming clear that opioids contribute a range of direct and indirect effects to the biology of solid tumours, to the anticancer immune response, inflammation, angiogenesis and importantly, to the tumour-promoting effects of pain. A common misconception in the literature is that the effect of opioid agonists equates the effect of the mu-opioid receptor, the major target of the analgesic effect of this class of drugs. We review the evidence on opioid receptor expression in cancer, opioid receptor polymorphisms and cancer outcome, the effect of opioid antagonists, especially the peripheral antagonist methylnaltrexone, and lastly, the evidence available of a role for opioids through non-opioid receptor mediated actions.

Keywords: opioid receptor, cancer, metastasis, TLR4, OGFr, opioid antagonist

\section{INTRODUCTION}

Opioids are administered to cancer patients to manage the pain associated with the disease, its treatment and in palliative care. The possibility that opioids may alter the course of cancer is therefore of high clinical relevance. Opioids given to cancer surgery patients in the perioperative period are of particular interest because despite the short time frame when they are administered, they have been hypothesised to contribute, together with a number of other optimisable variables, to long-term cancer outcome $(1,2)$.

In vitro and animal studies evaluating the influence of opioids on tumour growth and metastasis are abundant and highly discrepant, as reviewed elsewhere (3-5). A systematic review and metaanalysis of the ability of analgesic drugs to reduce metastasis in experimental cancer models concluded that opioids did not show a significant effect on the incidence of metastasis (6). Clinical studies have compared recurrence after cancer surgery employing regional anaesthesia and analgesia techniques, which allow pain control while reducing opioid exposure. Available at this 
time are a meta-analysis of several retrospective studies (7), randomised studies analysed a posteriori for cancer outcomes $(8,9)$, and a large-scale prospective randomised clinical trial comparing the suggested most tumour-protective anaesthetic strategy (regional anaesthesia and total intravenous anaesthesia) versus the proposed most tumour-promoting strategy (opioids plus volatile anaesthetics) (10). These studies, which are not designed to test the effect of opioids per se, use opioid-sparing techniques that have independent tumour modulating actions, and tend to combine disparate cancer types and patient-specific tumour genomics, have not elucidated whether opioids modulate the cancer-specific outcomes of surgery.

Numerous factors are likely to contribute to the lack of a net effect of opioids on tumour growth and metastasis in vivo. Opioids directly affect cancer cells as well as stromal cells that are key to the control of tumour growth and metastasis, especially immune and endothelial cells, and their pro-invasive paracrine cell-cell interaction $(11,12)$. The actions of opioids can result from their central or peripheral activity, at opioid as well as non-opioid receptors such as Toll-like receptor 4, which is abundantly expressed on immune cells and some cancer cells (13). In addition, the effect of opioids may indirectly stem from modulation of neuroendocrine responses, inflammation, stress and pain, all of which modulate tumour development (2). Opioids are broadly immunosuppressive and lower cellular and humoral responses, which may be of clinical relevance (1). However, because pain itself is immunosuppressive and promotes tumour growth and metastasis, opioids are protective against tumour growth and metastasis in animal models that incorporate pain $(14,15)$. Another variable factor is that not all opioids are equal, and their pharmacokinetic and pharmacodynamic characteristics may lead to differences in tumour-modulating properties. There is data to suggest that administration of opioids leading to continuous versus discontinuous opioid receptor activation may have different effects on cancer-relevant parameters $(16,17)$.

In view of these complexities, the present review seeks to distinguish the role of opioid analgesics from the role of opioid receptors particularly the mu-opioid receptor, the major target of the analgesic effect of this class of drugs. We review the evidence on increased opioid receptor expression in tumours, the literature investigating opioid receptor polymorphisms and cancer outcome, and the effect of opioid antagonists, especially the peripheral antagonist methyl naltrexone (MNTX). Finally, we suggest that the effects of opioids on non-opioid receptors, including but not limited to TLR4, may offer novel insights into the role of opioids on cancer in the future.

\section{OPIOID RECEPTOR EXPRESSION IN VARIOUS CANCER TYPES}

We searched the literature for studies comparing the expression of opioid receptors in cancer cells or tissues to that of relevant, healthy control cell or tissues. We used the following search protocol in PubMed: ("opioid receptor expression") AND (((cancer) OR (tumour)) OR (tumor)) and screened all the hits produced by the search up to September $10^{\text {th }}, 2021$, further adding relevant studies that were cited by these articles. The results are compiled in Table $\mathbf{1}$.

Altered opioid receptor expression in cancer has been observed as early as 1996 (28). Changes in expression of $\mu, \delta$, or $\kappa$-opioid receptors in cancer cells or tissues are reported in various cancer types and overall, point to an increased expression in cancer. The majority of studies described an increase in $\mu \mathrm{OR}$ (18-22), while some reports showed no significant differences in $\mu \mathrm{OR}$ expression levels between the tumour and adjacent nontumour tissues $(23,24)$. No studies reported a decreased expression of OR in cancer.

While $\mu$ OR has long been the focus of attention in the tumour microenvironment, $\delta \mathrm{OR}$ also showed an increase in expression compared to normal tissue (25-30), and interestingly, it is reported that the relative increase in $\delta \mathrm{OR}$ in malignant lesions is greater than that of the $\mu \mathrm{OR}(29,30)$. While $\kappa \mathrm{OR}$ has not been investigated as extensively as other receptors in the family, an increase in expression from healthy to cancerous tissue has been reported $(30,31)$.

Importantly, some studies attempted to link the level of OR expression in tumours to cancer aggressiveness or prognosis. For example, increased $\mu \mathrm{OR}$ in tumour tissue was associated with worse progression-free and overall survival in patients with metastatic, hormone sensitive prostate cancer (22) and low disease-free survival in laryngeal squamous cell carcinoma (20). Additionally, $\delta \mathrm{OR}$ expression was positively correlated with tumour metastasis, and receptor activation promoted proliferation in breast cancer cells (26). Similarly, $\kappa O R$ expression increases with tumour grade in oesophageal squamous cell carcinoma (31). In addition to the three commonly explored opioid receptors, McLauglin et al. investigated the expression of opioid growth factor receptor (OGFr), revealing no differences in receptor binding or gene expression between cancer cells in vitro and in small, medium, or large tumours (33).

Overall, the literature indicates increased expression of $\mathrm{OR}$ in cancer compared to healthy tissue, and links increased expression to stronger cancer aggressiveness. To evaluate whether OR expression may have a causal relationship with aggressiveness, we next reviewed studies where manipulation of OR expression was carried out and aggressive features measured as a readout.

\section{EFFECT OF OPIOID RECEPTOR MANIPULATION ON TUMOUR GROWTH AND AGGRESSIVENESS}

A number of studies investigated the effect of experimentally manipulating opioid receptor expression, e.g. through overexpression, mRNA silencing or gene disruption, in an attempt to demonstrate causality between receptor expression and change in tumour aggressive features. These studies are 
TABLE 1 | Studies documenting altered opioid receptor expression in cancer.

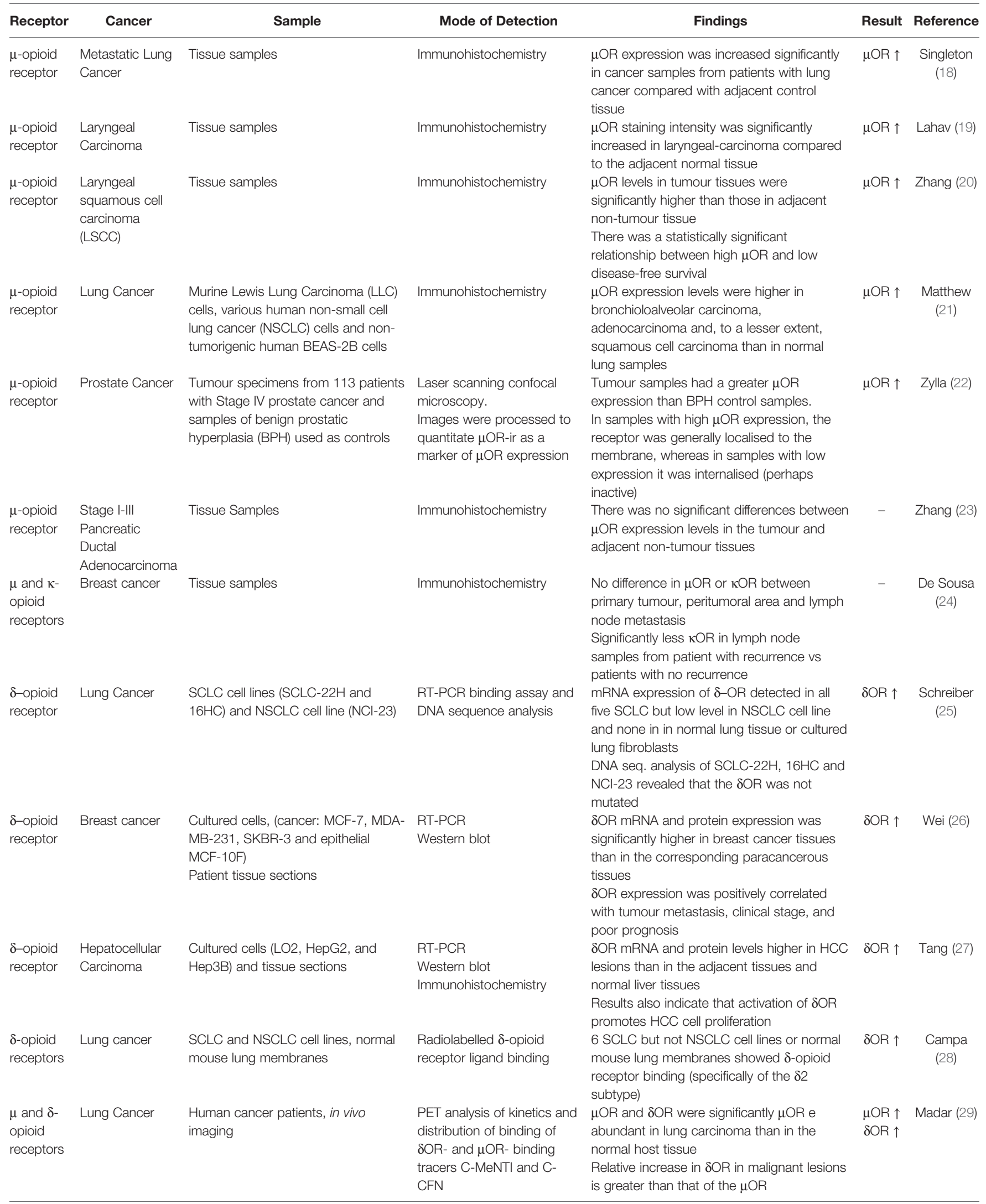


TABLE 1 | Continued

\begin{tabular}{|c|c|c|c|c|c|c|}
\hline Receptor & Cancer & Sample & Mode of Detection & Findings & Result & Reference \\
\hline $\begin{array}{l}\mu, \delta \text {, and } \\
\kappa \text {-opioid } \\
\text { receptors }\end{array}$ & $\begin{array}{l}\text { Stage I-III Triple } \\
\text { Negative Breast } \\
\text { Cancer }\end{array}$ & Publicly available bulk RNA-seq data & $\begin{array}{l}\text { RNA-seq analysis of tissue } \\
\text { or single cells }\end{array}$ & $\begin{array}{l}\mu O R \text { expression extremely low in both } \\
\text { cancer and normal tissue } \\
\kappa O R, \delta O R \text { and OGFR expression higher in } \\
\text { tumour vs normal tissue } \\
\kappa O R \text { mostly on cancer cells, OGFR mostly } \\
\text { on immune cells }\end{array}$ & $\begin{array}{l}\delta \mathrm{OR} \uparrow \\
\kappa \mathrm{OR} \uparrow\end{array}$ & $\begin{array}{l}\text { Montagna } \\
\text { (30) }\end{array}$ \\
\hline $\begin{array}{l}\mu, \delta \text {, and } \\
\kappa \text {-opioid } \\
\text { receptors }\end{array}$ & $\begin{array}{l}\text { Oesophageal } \\
\text { Squamous Cell } \\
\text { Carcinoma } \\
\text { (ESCC) }\end{array}$ & Cultured cells and tissue sections & $\begin{array}{l}\text { Flow cytometry } \\
\text { Immunocytochemistry } \\
\text { Western blot } \\
\text { Immunohistochemistry }\end{array}$ & 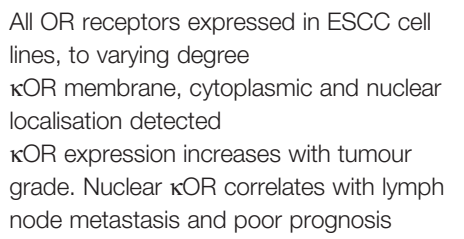 & $\kappa O R \uparrow$ & Zhang (31) \\
\hline $\begin{array}{l}\text { Opioid } \\
\text { Growth } \\
\text { Factor } \\
\text { receptor } \\
\text { (OGFr) }\end{array}$ & $\begin{array}{l}\text { Pancreatic and } \\
\text { colon cancer }\end{array}$ & $\begin{array}{l}\text { Human PaCa-2, BxPC-3, Capan-2 } \\
\text { (pancreatic) } \\
\text { HT-29, HCT } 116 \text { (colon) inoculated } \\
\text { into nude mice }\end{array}$ & $\begin{array}{l}\text { Receptor binding analysis } \\
\text { Northern blot }\end{array}$ & $\begin{array}{l}\text { No differences in receptor binding or gene } \\
\text { expression between cancer } \\
\text { cells in vitro and small, medium, or large } \\
\text { tumours }\end{array}$ & - & Zagon (32) \\
\hline
\end{tabular}

summarised in Table 2. It is important to note that few studies provide insight in the role of receptor expression in vivo, especially in the clinical setting.

The literature suggests a cancer-promoting role for the $\mu \mathrm{OR}$ in both cancer and non-cancer cells that support tumour growth. The siRNA downregulation of $\mu \mathrm{OR}$ inhibited aggressive features in lung cancer and squamous cell carcinoma of the head and neck in vitro $(21,34,36)$. Downregulation of $\mu \mathrm{OR}$ also decreased tumour take in the lungs after IV inoculation (21). Conversely, $\mu \mathrm{OR}$ overexpression promoted lung cancer cell line aggressiveness in vitro (36), and in vivo analysis of $\mu \mathrm{OR}$-overexpressing human bronchioloalveolar carcinoma cells xenografted to nude mice showed a marked

TABLE 2 | Effect of experimental manipulation of opioid receptor expression on tumour growth and aggressiveness.

\begin{tabular}{|c|c|c|c|c|}
\hline Receptor & Cancer & Manipulation/comparison & Findings & Reference \\
\hline $\begin{array}{l}\mu \text {-opioid } \\
\text { receptor }\end{array}$ & $\begin{array}{l}\text { Squamous Cell } \\
\text { Carcinoma of } \\
\text { the Head and } \\
\text { Neck }\end{array}$ & $\begin{array}{l}\text { siRNA down regulation of } \mu \mathrm{OR} \text { in FaDu } \\
\text { MDA686Tu and UMSCC } 47 \text { cultured cells }\end{array}$ & $\begin{array}{l}\text { In FaDu and MDA686Tu cells, downregulating } \mu \mathrm{OR} \text { expression inhibited } \\
\text { aggressive features }\end{array}$ & $\begin{array}{l}\text { Gorur A } \\
\text { (34) }\end{array}$ \\
\hline $\begin{array}{l}\mu \text {-opioid } \\
\text { receptor }\end{array}$ & Lung Cancer & $\begin{array}{l}\text { Lewis lung carcinoma (LLC) cells were } \\
\text { either transfected with control shRNA or } \\
\mu \mathrm{OR}-1 \text { shRNA }\end{array}$ & $\begin{array}{l}\text { Silencing (shRNA) } \mu O R \text { expression in LLC inhibits invasion and anchorage- } \\
\text { independent growth in vitro, and experimental metastasis in vivo. } \\
\mu O R \text {-deficient mice inoculated with LLC have reduced tumour formation. }\end{array}$ & $\begin{array}{l}\text { Matthew } \\
\text { (21) }\end{array}$ \\
\hline $\begin{array}{l}\mu \text {-opioid } \\
\text { receptor }\end{array}$ & Melanoma & $\begin{array}{l}\text { Wild-type and } \mu \mathrm{OR} \text { R-deficient mice were } \\
\text { inoculated with B16 melanoma cells that } \\
\text { secrete endogenous mu-opioid peptides }\end{array}$ & $\begin{array}{l}\mu \mathrm{OR} \text {-deficient mice demonstrated a marked reduction in tumour growth } \\
\text { and significantly higher infiltration of immune cells into the tumours when } \\
\text { inoculated with B16 melanoma cells }\end{array}$ & $\begin{array}{l}\text { Boehncke } \\
\text { (35) }\end{array}$ \\
\hline $\begin{array}{l}\mu \text {-opioid } \\
\text { receptor }\end{array}$ & Lung Cancer & $\begin{array}{l}\mu \mathrm{OR} \text {-overexpressing lung cancer } \\
\text { xenografts in nude mice } \\
\mu \mathrm{OR} \text { was inhibited with the peripheral } \mu \mathrm{OR} \\
\text { antagonist MNTX }\end{array}$ & $\begin{array}{l}\text { Overexpression of } \mu \mathrm{OR} \text { in cancer cells increased primary tumour growth } \\
\text { rates and lung metastases } \\
\text { Inhibiting } \mu \mathrm{OR} \text { attenuates EGF-induced proliferation and migration }\end{array}$ & Lennon (36) \\
\hline $\begin{array}{l}\mu \text {-opioid } \\
\text { receptor }\end{array}$ & $\begin{array}{l}\text { Non-Small Cell } \\
\text { Lung Cancer }\end{array}$ & $\begin{array}{l}\text { Stable vector control and } \mu \mathrm{OR} 1 \\
\text { overexpressing human bronchioloalveolar } \\
\text { carcinoma cells Xenografted to tumour- } \\
\text { bearing nude mice }\end{array}$ & $\begin{array}{l}\mu \mathrm{OR} \text { overexpression increased proliferation and extravasation } \\
\text { In vivo, overexpression of } \mu \mathrm{OR} \text { in human bronchoalveolar carcinoma cells } \\
\text { increased primary tumour growth rates in nude mice by approximately } 2.5 \text { - } \\
\text { fold and lung metastasis by approximately } 20 \text {-fold compared with vector } \\
\text { control cells }\end{array}$ & Lennon (37) \\
\hline $\begin{array}{l}\delta \text {-opioid } \\
\text { receptor }\end{array}$ & Breast Cancer & $\begin{array}{l}\text { MCF7 cells transduced with } \delta O R \text { siRNA or } \\
\text { control siRNA } \\
\text { Xenografted to tumour-bearing nude mice }\end{array}$ & SOR siRNA inhibits tumour growth in vitro and in vivo & $\begin{array}{l}\text { Wei Y-C } \\
\text { (26) }\end{array}$ \\
\hline $\begin{array}{l}\delta \text {-opioid } \\
\text { receptor }\end{array}$ & $\begin{array}{l}\text { Hepatocellular } \\
\text { Carcinoma }\end{array}$ & $\begin{array}{l}\text { siRNA down regulation of } \delta O R \text { in cultured } \\
\text { cells (LO2, HepG2, and Hep3B) }\end{array}$ & $\delta O R$ siRNA inhibits aggressiveness in vitro and in vivo & Tang (27) \\
\hline $\begin{array}{l}\mu \text { and } \delta- \\
\text { opioid } \\
\text { receptors }\end{array}$ & $\begin{array}{l}\text { Non-small Cell } \\
\text { Lung Cancer }\end{array}$ & H2009 Non-small Cell Lung Cancer cell line & $\begin{array}{l}\text { siRNA down regulation of either } \mu O R \text { and } \delta O R \text { decreases EGFR activation } \\
\text { by EGF and EGFR transactivation by morphine }\end{array}$ & Fujioka (38) \\
\hline $\begin{array}{l}\text { Opioid } \\
\text { Growth } \\
\text { Factor } \\
\text { receptor } \\
\text { (OGFr) }\end{array}$ & $\begin{array}{l}\text { Squamous Cell } \\
\text { Carcinoma of } \\
\text { the Head and } \\
\text { Neck }\end{array}$ & $\begin{array}{l}\text { human SCC-1 and clonal lines } \\
\text { overexpressing wild type OGFR or empty } \\
\text { vector }\end{array}$ & OGFR overexpression led to decreased cell proliferation & $\begin{array}{l}\text { McLaughlin } \\
\text { P (33) }\end{array}$ \\
\hline
\end{tabular}


increase in tumour growth rates compared to the stable vectortransfected control group (37). Interestingly, overexpressing the $\mu \mathrm{OR}$ led to increased in vitro (36) and in vivo (37) tumour growth or aggressiveness in the absence of any opioid added to culture medium or administered to mice. Furthermore, $\mu \mathrm{OR}$ genedisrupted mice had markedly reduced tumour formation compared to their wild type counterparts when inoculated with $\mu \mathrm{OR}$ expressing lung cancer cells, implying a role for the $\mu \mathrm{OR}$ in host cells (21). This was further demonstrated in experiments where $\mu \mathrm{OR}$-deficient mice or wild type controls were inoculated with B16 melanoma cells (35). The $\mu$ OR-deficient mice demonstrated a marked reduction in tumour growth compared to wild-type and the authors suggested this was due to inhibition by melanomasecreted $\beta$-endorphin of infiltration and proliferation of anti-cancer immune cells (35).

Two independent studies on $\delta$ OR siRNA showed that silencing the receptor inhibited tumour growth in vitro and in vivo in both breast (26) and liver (27) cancer. Another study on both $\mu \mathrm{OR}$ and $\delta \mathrm{OR}$ expression in lung cancer revealed that siRNA down regulation of either receptor decreased EGFR activation by EGF and EGFR transactivation by morphine (38).

Combined with the findings from Table 1, this would suggest that not only $\mu \mathrm{OR}$ and/or $\delta \mathrm{OR}$ expression is increased in cancerous cells or tissue, but overexpression also increases tumour growth and metastases. It is important to note that if ORs modulate tumour biology via activation by opioid, then their level of expression should be studied together with opioid dose-response, both in vitro and in vivo. If OR overexpression has functional consequences promoting tumour growth or metastasis, then OR mutations or polymorphisms that affect receptor function should lead to altered cancer outcomes.

\section{OPIOID RECEPTOR POLYMORPHISMS AND CANCER OUTCOME}

We next reviewed the existing literature assessing opioid receptor polymorphisms (Table 3). The A118G single-nucleotide polymorphism (SNP) of the $\mu \mathrm{OR}$ is the most frequent of all the $\mu \mathrm{OR}$ (OPRM1) gene variants, resulting in an amino acid change from asparagine to aspartate at position 40 of the $\mu \mathrm{OR}$, which leads to altered signalling and expression of the receptor $(45,46)$. The literature indicates that having the $\mathrm{G}$ allele results in higher $(42)$, or lower $(43,44)$ cancer risk, depending on the studies (different population; breast cancer or oesophageal cancer), while having the $G$ allele resulted in better (41) or unchanged $(39,40)$ outcomes after breast cancer surgery. These studies therefore do not provide a clear association between $\mu \mathrm{OR}$ function and cancer, however, it must be kept in mind that a number of confounders might be at play, since patients carrying the $G$ allele require higher opioid doses for pain management (46) and this polymorphism may also modulate drinking and smoking behaviours (45). We may see more studies evaluating genetic alteration of $\mu$ or other OR function and cancer in the future, but at present the evidence of a link between altered function of $\mu \mathrm{OR}$ and cancer outcome is inconsistent.

TABLE 3 | Opioid receptor polymorphisms and cancer outcome.

\begin{tabular}{|c|c|c|c|c|c|}
\hline $\begin{array}{l}\text { Receptor and } \\
\text { mutation }\end{array}$ & Cancer & Population & Method & Findings & Reference \\
\hline $\begin{array}{l}\mu \text {-opioid } \\
\text { receptor gene } \\
\text { A118G SNP } \\
\text { (AA, AG, GG } \\
\text { genotype) }\end{array}$ & $\begin{array}{l}\text { Breast } \\
\text { cancer }\end{array}$ & $\begin{array}{l}\text { Breast cancer or benign } \\
\text { biopsies from } \\
\text { Korean women } \\
n=200\end{array}$ & $\begin{array}{l}\text { Genotype } \\
\text { determined via } \\
\text { PCR of blood } \\
\text { sample }\end{array}$ & $\begin{array}{l}\text { Breast tumour recurrence was not influenced by A118G genotype in } \\
\text { Korean women }\end{array}$ & $\begin{array}{l}\text { Lee (39) } \\
\text { Oh }(40)\end{array}$ \\
\hline $\begin{array}{l}6 \mu \text {-opioid } \\
\text { receptor gene } \\
\text { polymorphisms } \\
\text { including } \\
\text { A118G } \\
\text { (AA, AG, GG } \\
\text { genotype) }\end{array}$ & $\begin{array}{l}\text { Breast } \\
\text { cancer }\end{array}$ & $\begin{array}{l}\text { Breast cancer biopsies from } \\
766 \text { African American and } \\
\text { 1,273 European American } \\
\text { women } \\
\mathrm{n}=2039\end{array}$ & $\begin{array}{l}\text { Genotype } \\
\text { determined via } \\
\text { PCR of blood } \\
\text { sample }\end{array}$ & $\begin{array}{l}\text { Of the six polymorphisms studied, the only one with a statistically } \\
\text { significant impact on mortality was A118G } \\
\text { Ten-year mortality was reduced in patients with at least one variant G } \\
\text { allele at A118GBeing heterozygous for AG genotype was significantly } \\
\text { protective over being homozygous for AA, with a reduced mortality rate of } \\
9 \% \text { compared to } 18 \% \\
\text { GG genotype at A118G was uncommon in the studied population, } \\
\text { precluding significant conclusions }\end{array}$ & $\begin{array}{l}\text { Bortsov } \\
(41)\end{array}$ \\
\hline $\begin{array}{l}\mu \text {-opioid } \\
\text { receptor } \\
\text { A118G } \\
\text { polymorphism }\end{array}$ & $\begin{array}{l}\text { Breast } \\
\text { Cancer }\end{array}$ & $\begin{array}{l}\text { North-eastern Polish } \\
\text { females recently diagnosed } \\
\text { with breast cancer } \\
n=741\end{array}$ & $\begin{array}{l}\text { Genotype } \\
\text { determined via } \\
\text { PCR of blood } \\
\text { sample }\end{array}$ & $\begin{array}{l}\text { G allele presence is strongly associated with increased breast cancer } \\
\text { incidence }\end{array}$ & $\begin{array}{l}\text { Cieślińska } \\
\text { (42) }\end{array}$ \\
\hline $\begin{array}{l}\mu \text {-opioid } \\
\text { receptor } \\
\text { A118G } \\
\text { polymorphism }\end{array}$ & $\begin{array}{l}\text { Oesophageal } \\
\text { Squamous } \\
\text { Cell } \\
\text { Carcinoma }\end{array}$ & $\begin{array}{l}\text { Chinese population } 490 \\
\text { ESCC patients and } 470 \\
\text { control subjects } \\
n=960\end{array}$ & $\begin{array}{l}\text { Genotype } \\
\text { determined via } \\
\text { PCR of blood } \\
\text { sample }\end{array}$ & $\begin{array}{l}\text { The frequency for the A allele of A118G was significantly higher in ESCC } \\
\text { cases } \\
\text { There was also a significant interaction between the A allele of A118G and } \\
\text { current smoking or alcohol consumption } \\
\text { Current smokers or drinkers with the A allele have the highest OSCC risk }\end{array}$ & Xu (43) \\
\hline $\begin{array}{l}\mu \text {-opioid } \\
\text { receptor } \\
\text { A118G } \\
\text { polymorphism }\end{array}$ & $\begin{array}{l}\text { Oesophageal } \\
\text { Squamous } \\
\text { Cell } \\
\text { Carcinoma }\end{array}$ & $\begin{array}{l}\text { Male and female OSCC } \\
\text { patients from Chinese } \\
\text { population } \\
\mathrm{n}=551\end{array}$ & $\begin{array}{l}\text { Genotype } \\
\text { determined via } \\
\text { PCR of blood } \\
\text { sample }\end{array}$ & AA genotype was associated with a significantly higher rate of OSCC & Wang (44) \\
\hline
\end{tabular}




\section{EFFECT OF OPIOID ANTAGONISTS ON TUMOUR GROWTH AND METASTASIS: PRECLINICAL STUDIES AND CLINICAL APPROACHES}

The role of opioid agonists in vitro and in vivo in preclinical studies has been evaluated and several reviews have concluded that opioids neither favour nor prevent cancer $(5,47,48,49-51)$ and elaborated on the potential reasons for the discrepancy (4). Due to this previous coverage, in the present review the effect of opioid agonists is deliberately not covered, however the next section will review the literature on opioid antagonists and cancer.

An in vitro study established that MNTX inhibits VEGFinduced activation of VEGF receptors 1 and 2 and consequent endothelial cell migration and proliferation, in vitro hallmarks of angiogenesis (52). MNTX similarly attenuated EGFinduced proliferation and migration of cultured human H358 NSCLC cells in a dose-dependent manner (36). MNTX exhibited synergistic effects when applied to cultured endothelial cells in combination with the antimetabolite 5Fluorouracil and the VEGF-monoclonal antibody Bevacizumab. The $\mathrm{IC}_{50}$ (concentration to achieve $50 \%$ inhibition of the target) were reduced from $5 \mu \mathrm{M}$ to $7 \mathrm{nM}$ and from $25 \mathrm{ng} / \mathrm{mL}$ to $6 \mathrm{ng} / \mathrm{mL}$, respectively, the potential clinical implications being increased effectiveness of 5Fluorouracil and Bevacizumab. However, the mechanism for the effect of MNTX involved a membrane-bound phosphatase acting on Src downstream of VEGFR. Together with the fact that naloxone and naltrexone did not replicate the effect of MNTX, these results show that the synergistic effect of MNTX on endothelial cells is non- $\mu$ opioid receptor mediated (53). A subsequent in vitro study from the same group showed similar synergy between MNTX and the mTOR inhibitors Temsirolimus and Rapamycin, reducing both of their $\mathrm{IC}_{50}$ for VEGF-induced proliferation and migration of endothelial cells. Furthermore, inhibition of tyrosine phosphate activity blocked this synergy, consolidating that the mechanism of synergy is non- $\mu$ opioid receptor mediated (54). Another study indicated MNTX potentiated the effect of the antitumour drug docetaxel in gastric cancer cells. In this study, growth inhibition induced by OGF was antagonised by MNTX, releasing the cells from dormancy and making them susceptible to docetaxel. Therefore, MNTX without docetaxel actually enhanced cell growth (55). Low dose naltrexone suppressed proliferation, migration and invasion of $\mathrm{HeLa}$ cells by increasing the expression of the tumour suppressor OGFr (56).

Animal studies indicate that the effect of OR antagonists in the whole organism involves complex interactions. Two studies were conducted using $\mu$-opioid receptor agonism or antagonism in murine models inoculated with neuroblastoma tumours. The first study analysed the opioid antagonist naloxone at doses ranging from $5 \mathrm{mg} / \mathrm{kg}$ to $20 \mathrm{mg} / \mathrm{kg}$ injected subcutaneously either two weeks before or one week after inoculation with the tumour cells. Compared with the control group of mice that received subcutaneous saline injections, both treatment groups experienced a statistically significant increase in survival time, ranging from a $20-61 \%$ increase with the higher naloxone doses (15 mg/kg and $20 \mathrm{mg} / \mathrm{kg}$ ) in both the pre-inoculation and postinoculation groups. Furthermore, the time to tumour appearance was prolonged by 6-21 days past the median 28 days observed in the control groups. Tumour size was also reduced, however, at the time of death there was no difference in tumour sizes between any of the groups, implying the delay in tumour development as the cause of the size disparity (57). The second study employed the opioid agonist heroin at doses of $3 \mathrm{mg} / \mathrm{kg}$ to $15 \mathrm{mg} / \mathrm{kg}$ in the same murine model. Importantly, the results of this study showed a statistically significant prolonged mean survival time of $32-39 \%$ across all groups when compared to the control, however, no correlation between dose and mean survival time was observed and like in the naloxone study, there was no difference in mean tumour size at the time of death. Interestingly, these anti-tumour effects of heroin were negated by simultaneous administration of naloxone, despite the previous study suggesting its similar effects (58). These studies indicated that both agonism and antagonism of opioid receptor (s) were protective in a rodent experimental tumour model.

Zagon and McLaughlin then exposed the complexity of in vivo effects of naltrexone in a study using different dosing regimens: in mice inoculated intradermally with syngeneic neuroblastoma cells, subcutaneous administration of $0.1 \mathrm{mg} / \mathrm{kg}$ naltrexone daily led to a reduction in tumour incidence, delay in the time before the tumour appeared and increase in the mean $(42 \%)$ and median (36\%) survival times. However, increasing the dose of naltrexone to $1 \mathrm{mg} / \mathrm{kg}$ was less efficacious than $0.1 \mathrm{mg} / \mathrm{kg}$, with the $1 \mathrm{mg} / \mathrm{kg}$ group showing no statistically significant reduction in tumour appearance after 29 days, and a survival time comparable to that of the controls. Strikingly, the group receiving $10 \mathrm{mg} / \mathrm{kg}$ had statistically significant shorter mean (19\%) and median (22\%) survival times as well as a reduced time to tumour appearance. Furthermore, this was the only group with a statistically significant difference in the size of tumour at time of death, with an increased mean from $26.2 \mathrm{~mm}$ to $32.4 \mathrm{~mm}$ (17). How could a low dose of naltrexone be protective, a medium dose have no effect and a high dose be deleterious? The study went on to test the time course of antagonism provided by each regimen and showed that opioid agonism was blocked during 4-6 hours per day in the $0.1 \mathrm{mg} / \mathrm{kg}$ group and 24 hours per day in the $10 \mathrm{mg} / \mathrm{kg}$ group. Since OR antagonists have been shown to increase MOR expression and endorphin production (59-62), the authors proposed that with the lower naltrexone dosage, $\mu$ ORs were available for activation by endogenous opioid agonists during 19-20 hours per day (17). The authors further reported that the antineoplastic potential of $0.1 \mathrm{mg} / \mathrm{kg}$ of naltrexone in a mouse model was not accompanied by a change in metastasis (63). This set of studies underlines the importance of opioid antagonists pharmacokinetics and pharmacodynamics in their anti-cancer effects, and somewhat reconciles the previous findings that both agonists and 
antagonists offered protection, by suggesting that the antagonists increase the sensitivity to endogenous agonists that are actually protective. This is supported by the antineoplastic activity of $\beta$ endorphin shown in vivo in models of breast carcinogenesis (64, 65), and antagonised by naloxone (64). Similarly, low dose naltrexone enhanced serum concentrations of beta-endorphin and met-enkephalin and survival rates in dogs with mammary carcinoma (66). Low dose naltrexone was also protective in a murine model of solid Ehrlich carcinoma by increasing the expression of the tumour suppressor OGF receptor (67).

Naltrexone fed to tumour-bearing rats significantly decreased the size of established tumours while tumours continued to grow in control-fed rats when mammary tumours were induced by 7,12-dimethylbenz (a)anthracene (DMBA). After 25 days of receiving a $75 \mathrm{mg} / \mathrm{kg}$ naltrexone-supplemented diet, the volume of the mammary tumours was decreased by $23 \%$ compared to the control group. Furthermore, tumour regression was observed in $70 \%$ of the treatment group. Interestingly, the naltrexoneresponsive tumours showed observable amounts of oestrogen and progesterone receptors, contrasting with the unresponsive tumours which were progesterone and oestrogen receptornegative (68). Moreover, naltrexone administered per os to rats in the initiation, promotion or both phases of mammary tumorigenesis upon exposure to DMBA decreased tumour incidence and multiplicity when compared to control (69). Naltrexone's inhibitory effects on mammary carcinomas were maximised when the diet was supplemented during the promotion phase of carcinogenesis (69).

The implications of the murine studies were inevitably studying of the tumour-suppressive potential of opioid antagonists in a clinical setting. The first of these studies was conducted in 1993 on 21 patients with malignant gliomas being treated with radiotherapy. These patients were randomised to radiotherapy alone (control) and radiotherapy plus Naltrexone. In the combination group a $40 \%$ increase in the overall survival at one year was reported (70). Extensive evidence supports that opioid antagonists can effectively be employed in the prevention and treatment of opioid-induced constipation in cancer patients (71). A post-hoc analysis was conducted on a cohort of patients with advanced cancer being treated with MNTX for opioidinduced constipation. The difference in the median overall survival was statistically significant favouring those being treated with MNTX. Comparison with seriously ill, non-cancer patients in the same study that had no increase in the median overall survival, hints at potential anti-cancer effects of MNTX (72).

\section{EVIDENCE THAT OPIOIDS MAY INFLUENCE CANCER OUTCOMES VIA OTHER RECEPTORS}

In this last section, we highlight the growing awareness that some of the effects of opioids on cancer may not be mediated by the classical $\mu, \delta$ or $\kappa$ OR. The role of Toll-like receptor 4 (TLR4) in this context has been reviewed elsewhere (73). In brief, TLR4 is a major player of the innate immune response and is expressed by immune cells of the tumour microenvironment as well as cancer cells (30). TLR4 signalling in cancer cells increases their ability to invade $(74,75)$. Chronic TLR4 activation promotes an inflammatory environment conducive to carcinogenesis, but TLR4 is necessary to the elimination of dying cancer cells upon radio or chemotherapy (76) and perioperative treatment with a TLR4 agonist in rats and mice reduces cancer metastasis (77). Some opioids, including opioid metabolites or isomers inactive at ORs, have been shown to weakly activate TLR4 (13, 16) and a range of opiates, both agonists and antagonists of ORs, prevent activation of TLR 4 by its natural ligand lipopolysaccharide $(16,78)$. From these interactions, the net effect of opioids acting on TLR4 on the course of cancer cannot be predicted.

The literature offers insight into non OR-mediated effects of opioids that are relevant to cancer. Fentanyl was recently shown to inhibit acute myeloid leukemia cell growth synergistically with cytarabine via an opioid receptor-independent mechanism of suppression of Ras and STAT5 pathways (79). A recent clinical study evaluated the interaction between opioid dose administered intraoperatively, canonical oncogenic pathway gene mutation in lung tumours, and recurrence. Alterations of the Wnt and Hippo pathways were associated with improved 5year recurrence-specific survival with increasing opioid exposure (80). The signalling events linking opioids to these known oncogenic pathways remain to be explored. Opioid-binding protein/cell adhesion molecule-like (OPCML) is a GPIanchored protein functioning as a tumour-suppressor gene that attenuates multiple receptor tyrosine kinases (81). It was discovered based on an opioid binding strategy of protein purification from the brain and proposed to modulate OR expression and function. Importantly, its expression was reduced in neuronal cells treated by $\delta \mathrm{OR}$ agonists (82). Lastly, we included the OGFr in our search for evidence of ORs expression in cancer even though it is not a classical opioid receptor. The nuclear membrane receptor OGFr, which responds to the endogenous opioid peptides OGF or met-enkephalin, is a known negative regulator of cell proliferation, which controls, amongst other processes, tumour growth and angiogenesis (83). OGFr responds to naltrexone resulting in suppression of cell proliferation, and upregulation of the OGFr (84).

\section{CONCLUDING REMARKS}

Our review focused on ORs to highlight the complexity of the role of opioids in cancer. Although the literature points to an overexpression of ORs in cancer, and experimental manipulation of OR expression overall seems to correlate with cancer aggressiveness, the view that opioid agonists promote, and opioid antagonists prevent cancer is oversimplistic. The literature linking $\mu \mathrm{OR}$ mutations that impair receptor function to cancer risk or prognosis in patients does not, to date, offer a clear picture. Studies evaluating the effect of $\mu \mathrm{OR}$ antagonists suggest a protective action in the context of cancer, however the protection they afford is much 
more nuanced than merely antagonising the ORs; the pharmacokinetics and pharmacodynamics of antagonists and endogenous or exogenous agonists, and feedback on receptor expression, must be evaluated. Lastly, future studies investigating the effect of opioids on non-opioid receptors may contribute to elucidating the role of opioids in cancer.

\section{REFERENCES}

1. Sessler DI, Ben-Eliyahu S, Mascha EJ, Parat MO, Buggy DJ. Can Regional Analgesia Reduce the Risk of Recurrence After Breast Cancer? Methodology of a Multicenter Randomized Trial. Contemp Clin Trials (2008) 29(4):517-26. doi: 10.1016/j.cct.2008.01.002

2. Horowitz M, Neeman E, Sharon E, Ben-Eliyahu S. Exploiting the Critical Perioperative Period to Improve Long-Term Cancer Outcomes. Nat Rev Clin Oncol (2015) 12(4):213-26. doi: 10.1038/nrclinonc.2014.224

3. Afsharimani B, Cabot P, Parat MO. Morphine and Tumor Growth and Metastasis. Cancer metastasis Rev (2011) 30(2):225-38. doi: 10.1007/s10555011-9285-0

4. Afsharimani B, Doornebal CW, Cabot PJ, Hollmann MW, Parat MO. Comparison and Analysis of the Animal Models Used to Study the Effect of Morphine on Tumour Growth and Metastasis. Br J Pharmacol (2015) 172 (2):251-9. doi: 10.1111/bph.12589

5. Xie N, Parat M-O. Opioid Analgesic Agents and Cancer Cell Biology. Curr Anesthesiology Rep (2015) 5(3):278-84. doi: 10.1007/s40140-015-0118-5

6. Hooijmans CR, Geessink FJ, Ritskes-Hoitinga M, Scheffer GJ. A Systematic Review and Meta-Analysis of the Ability of Analgesic Drugs to Reduce Metastasis in Experimental Cancer Models. Pain (2015) 156(10):1835-44. doi: 10.1097/j.pain.0000000000000296

7. Chen W-K, Miao C-H. The Effect of Anesthetic Technique on Survival in Human Cancers: A Meta-Analysis of Retrospective and Prospective Studies. PloS One (2013) 8(2):e56540. doi: 10.1371/journal.pone.0056540

8. Myles PS, Peyton P, Silbert B, Hunt J, Rigg JR, Sessler DI. Perioperative Epidural Analgesia for Major Abdominal Surgery for Cancer and RecurrenceFree Survival: Randomised Trial. BMJ (2011) 342:d1491. doi: 10.1136/ bmi.d1491

9. Du YT, Li YW, Zhao BJ, Guo XY, Feng Y, Zuo MZ, et al. Long-Term Survival After Combined Epidural-General Anesthesia or General Anesthesia Alone: Follow-Up of a Randomized Trial. Anesthesiology (2021) 135(2):233-45. doi: 10.1097/ALN.0000000000003835

10. Sessler DI, Pei L, Huang Y, Fleischmann E, Marhofer P, Kurz A, et al. Recurrence of Breast Cancer After Regional or General Anaesthesia: A Randomised Controlled Trial. Lancet (2019) 394(10211):1807-15. doi: 10.1016/S0140-6736(19)32313-X

11. Khabbazi S, Goumon Y, Parat MO. Morphine Modulates Interleukin-4- or Breast Cancer Cell-Induced Pro-Metastatic Activation of Macrophages. Sci Rep (2015) 5:11389. doi: 10.1038/srep11389

12. Khabbazi S, Nassar ZD, Goumon Y, Parat M-O. Morphine Decreases the ProAngiogenic Interaction Between Breast Cancer Cells and Macrophages In Vitro. Sci Rep (2016) 6:31572. doi: 10.1038/srep31572

13. Hutchinson MR, Zhang Y, Shridhar M, Evans JH, Buchanan MM, Zhao TX, et al. Evidence That Opioids may Have Toll-Like Receptor 4 and MD-2 Effects. Brain Behavior Immun (2010) 24(1):83-95. doi: 10.1016/ j.bbi.2009.08.004

14. Page GG, Blakely WP, Ben-Eliyahu S. Evidence That Postoperative Pain is a Mediator of the Tumor-Promoting Effects of Surgery in Rats. Pain (2001) 90 (1-2):191-9. doi: 10.1016/S0304-3959(00)00403-6

15. Sasamura T, Nakamura S, Iida Y, Fujii H, Murata J, Saiki I, et al. Morphine Analgesia Suppresses Tumor Growth and Metastasis in a Mouse Model of Cancer Pain Produced by Orthotopic Tumor Inoculation. Eur J Pharmacol (2002) 441(3):185-91. doi: 10.1016/S0014-2999(02)01450-4

16. Xie N, Gomes FP, Deora V, Gregory K, Vithanage T, Nassar ZD, et al. Activation of $\mu$-Opioid Receptor and Toll-Like Receptor 4 by Plasma From

\section{AUTHOR CONTRIBUTIONS}

Writing - original draft preparation, CS, ZS, and M-OP. Writing -review and editing, CS, ZS, M-OP, and MH. Supervision, M-OP. Clinical validation, MH. All authors have read and agreed to the published version of the manuscript.

Morphine-Treated Mice. Brain Behavior Immun (2017) 61:244-58. doi 10.1016/j.bbi.2016.12.002

17. Zagon IS, McLaughlin PJ. Naltrexone Modulates Tumor Response in Mice With Neuroblastoma. Science (1983) 221(4611):671-3. doi: 10.1126/science.6867737

18. Singleton PA, Mirzapoiazova T, Hasina R, Salgia R, Moss J. Increased $\mu$ Opioid Receptor Expression in Metastatic Lung Cancer. Br J Anaesth. (2014) 113 Suppl 1(Suppl 1):i103-8. doi: 10.1093/bja/aeu165

19. Lahav Y, Cohen O, Huszar M, Levy I, Cata JP, Halperin D, et al. Mu-Opioid Receptor Expression in Laryngeal Cancer. J Voice (2021). doi: 10.1016/ j.jvoice.2021.02.018

20. Zhang H, Sun M, Zhou D, Gorur A, Sun Z, Zeng W, et al. Increased MuOpioid Receptor Expression is Associated With Reduced Disease-Free and Overall Survival in Laryngeal Squamous Cell Carcinoma. Br J Anaesth (2020) 125(5):722-9. doi: 10.1016/j.bja.2020.07.051

21. Mathew B, Lennon FE, Siegler J, Mirzapoiazova T, Mambetsariev N, Sammani $\mathrm{S}$, et al. The Novel Role of the Mu Opioid Receptor in Lung Cancer Progression: A Laboratory Investigation. Anesth Analg (2011) 112(3):55867. doi: 10.1213/ANE.0b013e31820568af

22. Zylla D, Gourley BL, Vang D, Jackson S, Boatman S, Lindgren B, et al. Opioid Requirement, Opioid Receptor Expression, and Clinical Outcomes in Patients With Advanced Prostate Cancer. Cancer (2013) 119(23):4103-10. doi: 10.1002/cncr.28345

23. Zhang H, Qu M, Gorur A, Sun Z, Cata JP, Chen W, et al. Association of MuOpioid Receptor (MOR) Expression and Opioids Requirement With Survival in Patients With Stage I-III Pancreatic Ductal Adenocarcinoma. Front Oncol (2021) 11:686877. doi: 10.3389/fonc.2021.686877

24. de Sousa AM, Dantas TS, de Barros Silva PG, da Silva Martins C, Freire GE, Junior HLR, et al. Analysis of the Immunoexpression of Opioid Receptors and Their Correlation With Markers of Angiogenesis, Cell Proliferation and Apoptosis in Breast Cancer. Asian Pacific J Cancer Prev APJCP (2021) 22 (2):633-40. doi: 10.31557/APJCP.2021.22.2.633

25. Schreiber G, Campa MJ, Prabhakar S, O'Briant K, Bepler G, Patz EFJr. Molecular Characterization of the Human Delta Opioid Receptor in Lung Cancer. Anticancer Res (1998) 18(3a):1787-92.

26. Wei Y-C, Zhang B, Li X, Liu X-M, Zhang J, Lei B, et al. Upregulation and Activation of $\delta$-Opioid Receptors Promotes the Progression of Human Breast Cancer. Oncol Rep (2016) 36(5):2579-86. doi: 10.3892/or.2016.5109

27. Tang BO, Li Y, Yuan S, Tomlinson S, He S. Upregulation of the $\delta$ Opioid Receptor in Liver Cancer Promotes Liver Cancer Progression Both In Vitro and In Vivo. Int J Oncol (2013) 43(4):1281-90. doi: 10.3892/ijo.2013.2046

28. Campa MJ, Schreiber G, Bepler G, Bishop MJ, McNutt RW, Chang K-J, et al. Characterization of $\delta$ Opioid Receptors in Lung Cancer Using a Novel Nonpeptidic Ligand. Cancer Res (1996) 56(7):1695-701.

29. Madar I, Bencherif B, Lever J, Heitmiller RF, Yang SC, Brock M, et al. Imaging Delta- and Mu-Opioid Receptors by PET in Lung Carcinoma Patients. J Nucl Med (2007) 48(2):207-13.

30. Montagna G, Gupta HV, Hannum M, Tan KS, Lee J, Scarpa JR, et al. Intraoperative Opioids are Associated With Improved Recurrence-Free Survival in Triple-Negative Breast Cancer. Br J Anaesth (2021) 126(2):36776. doi: 10.1016/j.bja.2020.10.021

31. Zhang Y-FP, Xu Q-XMD, Liao L-DBA, Xu X-EB, Wu J-YB, Shen JB, et al. $\kappa$ -Opioid Receptor in the Nucleus is a Novel Prognostic Factor of Esophageal Squamous Cell Carcinoma. Hum Pathol (2013) 44(9):1756-65. doi: 10.1016/ j.humpath.2012.11.025

32. Zagon IS, McLaughlin PJ. Opioid Growth Factor Receptor is Unaltered With the Progression of Human Pancreatic and Colon Cancers. Int J Oncol (2006) 29(2):489-94. doi: 10.3892/ijo.29.2.489 
33. McLaughlin P, Verderame M, Hankins J, Zagon I. Overexpression of the Opioid Growth Factor Receptor Downregulates Cell Proliferation of Human Squamous Carcinoma Cells of the Head and Neck. Int J Mol Med (2007) 19 (3):421-8. doi: 10.3892/ijmm.19.3.421

34. Gorur A, Patiño M, Shi T, Corrales G, Takahashi H, Rangel R, et al. Low Doses of Methylnaltrexone Inhibits Head and Neck Squamous Cell Carcinoma Growth In Vitro and In Vivo by Acting on the Mu-Opioid Receptor. J Cell Physiol (2021) 236(11):7698-710. doi: 10.1002/jcp.30421

35. Boehncke S, Hardt K, Schadendorf D, Henschler R, Boehncke WH, Duthey B. Endogenous $\mu$-Opioid Peptides Modulate Immune Response Towards Malignant Melanoma. Exp Dermatol (2011) 20(1):24-8. doi: 10.1111/j.16000625.2010.01158.x

36. Lennon FE, Mirzapoiazova T, Mambetsariev B, Poroyko VA, Salgia R, Moss J, et al. The $\mathrm{Mu}$ Opioid Receptor Promotes Opioid and Growth Factor-Induced Proliferation, Migration and Epithelial Mesenchymal Transition (EMT) in Human Lung Cancer. PloS One (2014) 9(3):e91577. doi: 10.1371/journal.pone.0091577

37. Lennon FE, Mirzapoiazova T, Mambetsariev B, Salgia R, Moss J, Singleton PA. Overexpression of the $\mu$-Opioid Receptor in Human non-Small Cell Lung Cancer Promotes Akt and mTOR Activation, Tumor Growth, and Metastasis. Anesthesiology (2012) 116(4):857-67. doi: 10.1097/ALN.0b013e31824babe2

38. Fujioka N, Nguyen J, Chen C, Li Y, Pasrija T, Niehans G, et al. Morphine-Induced Epidermal Growth Factor Pathway Activation in non-Small Cell Lung Cancer. Anesth Analg (2011) 113(6):1353-64. doi: 10.1213/ANE.0b013e318232b35a

39. Lee YJ, Oh CS, Choi JM, Park S, Kim SH. Mu-Opioid Receptor Polymorphisms and Breast Cancer Recurrence in Adult Korean Women Undergoing Breast Cancer Surgery: A Retrospective Study. Int J Med Sci (2020) 17(18):2941-6. doi: 10.7150/ijms.49297

40. Oh CS, Lee SH, Yoo YB, Yang JH, Kim SH. Mu-Opioid Receptor Polymorphisms and Breast Cancer in a Korean Female Adult Population: A Retrospective Study. J Breast Cancer (2016) 19(2):206-9. doi: 10.4048/jbc.2016.19.2.206

41. Bortsov AV, Millikan RC, Belfer I, Boortz-Marx RL, Arora H, McLean SA. $\mu$ Opioid Receptor Gene A118G Polymorphism Predicts Survival in Patients With Breast Cancer. Anesthesiology (2012) 116(4):896-902. doi: 10.1097/ ALN.0b013e31824b96a1

42. Cieślińska A, Sienkiewicz-Szłapka E, Kostyra E, Fiedorowicz E, Snarska J, Wroński $\mathrm{K}$, et al. $\mu$-Opioid Receptor Gene (OPRM1) Polymorphism in Patients With Breast Cancer. Tumor Biol (2015) 36(6):4655-60. doi: 10.1007/s13277-015-3113-z

43. Xu X, Mao B, Wu L, Liu L, Rui J, Chen G. A118G Polymorphism in $\mu$-Opioid Receptor Gene and Interactions With Smoking and Drinking on Risk of Oesophageal Squamous Cell Carcinoma. J Clin Lab Anal (2017) 31(1):e22018. doi: $10.1002 /$ jcla.22018

44. Wang S, Li Y, Liu X-D, Zhao C-X, Yang K-Q. Polymorphism of A118G in $\mu$ Opioid Receptor Gene is Associated With Risk of Esophageal Squamous Cell Carcinoma in a Chinese Population. Int J Clin Oncol (2013) 18(4):666-9. doi: 10.1007/s10147-012-0441-5

45. Crist RC, Berrettini WH. Pharmacogenetics of OPRM1. Pharmacol Biochem Behav (2014) 123:25-33. doi: 10.1016/j.pbb.2013.10.018

46. Yu Z, Wen L, Shen X, Zhang H. Effects of the OPRM1 A118G Polymorphism (Rs1799971) on Opioid Analgesia in Cancer Pain: A Systematic Review and MetaAnalysis. Clin J Pain (2019) 35(1):77-86. doi: 10.1097/AJP.0000000000000636

47. Tregubenko P, Zvonarev V. Impact of Opioid Use in Hematological Malignancies: Clinical, Immunological and Concomitant Aspects. J Hematol (2020) 9(3):41-54. doi: 10.14740/jh689

48. Carli M, Donnini S, Pellegrini C, Coppi E, Bocci G. Opioid Receptors Beyond Pain Control: The Role in Cancer Pathology and the Debated Importance of Their Pharmacological Modulation. Pharmacol Res (2020) 159:104938. doi: 10.1016/j.phrs.2020.104938

49. Tuerxun H, Cui J. The Dual Effect of Morphine on Tumor Development. Clin Transl Oncol (2019) 21(6):695-701. doi: 10.1007/s12094-018-1974-5

50. Sekandarzad MW, Doornebal C, Hollmann MW. Opiophobia in Cancer BiologyJustified? - The Role of Perioperative Use of Opioids in Cancer Recurrence. Curr Pharm Des (2019) 25(28):3020-7. doi: 10.2174/1381612825666190703163329

51. Zhang XY, Liang YX, Yan Y, Dai Z, Chu HC. Morphine: Double-Faced Roles in the Regulation of Tumor Development. Clin Transl Oncol (2018) 20 (7):808-14. doi: 10.1007/s12094-017-1796-x

52. Singleton PA, Lingen MW, Fekete MJ, Garcia JGN, Moss J. Methylnaltrexone Inhibits Opiate and VEGF-Induced Angiogenesis: Role of Receptor Transactivation. Microvascular Res (2006) 72(1-2):3-11. doi: 10.1016/j.mvr.2006.04.004
53. Singleton PA, Garcia JG, Moss J. Synergistic Effects of Methylnaltrexone With 5-Fluorouracil and Bevacizumab on Inhibition of Vascular Endothelial Growth Factor-Induced Angiogenesis. Mol Cancer Ther (2008) 7(6):166979. doi: 10.1158/1535-7163.MCT-07-2217

54. Singleton PA, Mambetsariev N, Lennon FE, Mathew B, Siegler JH, MorenoVinasco L, et al. Methylnaltrexone Potentiates the Anti-Angiogenic Effects of mTOR Inhibitors. J Angiogenes Res (2010) 2(1):5. doi: 10.1186/2040-2384-2-5

55. Suzuki M, Chiwaki F, Sawada Y, Ashikawa M, Aoyagi K, Fujita T, et al. Peripheral Opioid Antagonist Enhances the Effect of Anti-Tumor Drug by Blocking a Cell Growth-Suppressive Pathway In Vivo. PloS One (2015) 10(4): e0123407. doi: 10.1371/journal.pone.0123407

56. Liu N, Ma M, Qu N, Wang R, Chen H, Hu F, et al. Low-Dose Naltrexone Inhibits the Epithelial-Mesenchymal Transition of Cervical Cancer Cells In Vitro and Effects Indirectly on Tumor-Associated Macrophages In Vivo. Int Immunopharmacol (2020) 86:106718. doi: 10.1016/j.intimp.2020.106718

57. Zagon IS, McLaughlin PJ. Naloxone Prolongs the Survival Time of Mice Treated With Neuroblastoma. Life Sci (1981) 28(10):1095-102. doi: 10.1016/ 0024-3205(81)90686-X

58. Zagon IS, McLaughlin PJ. Heroin Prolongs Survival Time and Retards Tumor Growth in Mice With Neuroblastoma. Brain Res Bull (1981) 7(1):25-32. doi: 10.1016/0361-9230(81)90094-0

59. Lahti RA, James Collins R. Chronic Naloxone Results in Prolonged Increases in Opiate Binding Sites in Brain. Eur J Pharmacol (1978) 51(2):185-6. doi: 10.1016/0014-2999(78)90343-6

60. Schulz R, Wüster M, Herz A. Supersensitivity to Opioids Following the Chronic Blockade of Endorphin Action by Naloxone. Naunyn Schmiedebergs Arch Pharmacol (1979) 306(1):93-6. doi: 10.1007/BF00515600

61. Zukin RS, Sugarman JR, Fitz-Syage ML, Gardner EL, Zukin SR, Gintzler AR. Naltrexone-Induced Opiate Receptor Supersensitivity. Brain Res (1982) 245 (2):285-92. doi: 10.1016/0006-8993(82)90811-3

62. Recant L, Voyles NR, Luciano M, Pert CB. Naltrexone Reduces Weight Gain, Alters "Beta-Endorphin", and Reduces Insulin Output From Pancreatic Islets of Genetically Obese Mice. Peptides (1980) 1(4):309-13. doi: 10.1016/01969781(80)90008-X

63. Zagon IS MP. Opioid Antagonists Inhibit the Growth of Metastatic Murine Neuroblastoma. Cancer Lett (1983) 21(1):89-94.

64. Sarkar DK, Zhang C, Murugan S, Dokur M, Boyadjieva NI, Ortigela M, et al. Transplantation of + -Endorphin Neurons Into the Hypothalamus Promotes Immune Function and Restricts the Growth and Metastasis of Mammary Carcinoma. Cancer Res (2011) 71(19):6282-91. doi: 10.1158/0008-5472.CAN-11-1610

65. Zhang C, Franklin T, Sarkar DK. Inhibition of Mammary Cancer Progression in Fetal Alcohol Exposed Rats by $\beta$-Endorphin Neurons. Alcohol Clin Exp Res (2016) 40(1):134-40. doi: 10.1111/acer.12941

66. Machado MC, da Costa-Neto JM, Portela RD, D'Assis M, Martins-Filho OA, Barrouin-Melo SM, et al. The Effect of Naltrexone as a Carboplatin Chemotherapy-Associated Drug on the Immune Response, Quality of Life and Survival of Dogs With Mammary Carcinoma. PloS One (2018) 13(10): e0204830. doi: 10.1371/journal.pone.0204830

67. Aboalsoud A, El-Ghaiesh SH, Abd Elmonem FF, Salem ML, Abdel Rahman MN. The Effect of Low-Dose Naltrexone on Solid Ehrlich Carcinoma in Mice: The Role of OGFr, BCL2, and Immune Response. Int Immunopharmacol (2020) 78:106068. doi: 10.1016/j.intimp.2019.106068

68. Abou-Issa H, Tejwani GA. Antitumor Activity of Naltrexone and Correlation With Steroid Hormone Receptors. Biochem Biophys Res Commun (1991) 175 (2):625-30. doi: 10.1016/0006-291X(91)91611-F

69. Koo KL, Tejwani GA, Abou-Issa H. Relative Efficacy of the Opioid Antagonist, Naltrexone, on the Initiation and Promotion Phases of Rat Mammary Carcinogenesis. Anticancer Res (1996) 16(4a):1893-8.

70. Lissoni P, Meregalli S, Fossati V, Barni S, Tancini G, Barigozzi P, et al. Radioendocrine Therapy of Brain Tumors With the Long Acting Opioid Antagonist Naltrexone in Association With Radiotherapy. Tumori (1993) 79 (3):198-201. doi: 10.1177/030089169307900308

71. Mehta N OC, Giambrone GP, Baqai A, Diwan S. Efficacy of Methylnaltrexone for the Treatment of Opiod-Induced Constipation: A Meta-Analysis and Systematic Review. Postgraduate Med (2016) 128(3):282-9. doi: 10.1080/ 00325481.2016.1149017

72. Janku F JL, Karp DD, Atkins JT, Singleton PA, Moss J. Treatment With Methylnaltrexone is Associated With Increased Survival in Patients With 
Advanced Cancer. Ann Oncol (2016) 27(11):2032-8. doi: 10.1093/annonc/ mdw317

73. Gabr MM, Saeed I, Miles JA, Ross BP, Shaw PN, Hollmann MW, et al. Interaction of Opioids With TLR4-Mechanisms and Ramifications. Cancers (2021) 13(21):5274. doi: 10.3390/cancers13215274

74. Molteni M, Marabella D, Orlandi C, Rossetti C. Melanoma Cell Lines are Responsive In Vitro to Lipopolysaccharide and Express TLR-4. Cancer Lett (2006) 235(1):75-83. doi: 10.1016/j.canlet.2005.04.006

75. Ikebe M, Kitaura Y, Nakamura M, Tanaka H, Yamasaki A, Nagai S, et al. Lipopolysaccharide (LPS) Increases the Invasive Ability of Pancreatic Cancer Cells Through the TLR4/MyD88 Signaling Pathway. J Surg Oncol (2009) 100 (8):725-31. doi: 10.1002/jso.21392

76. Apetoh L, Ghiringhelli F, Tesniere A, Obeid M, Ortiz C, Criollo A, et al. Toll-Like Receptor 4-Dependent Contribution of the Immune System to Anticancer Chemotherapy and Radiotherapy. Nat Med (2007) 13:1050. doi: 10.1038/nm1622

77. Matzner P, Sorski L, Shaashua L, Elbaz E, Lavon H, Melamed R, et al. Perioperative Treatment With the New Synthetic TLR-4 Agonist GLA-SE Reduces Cancer Metastasis Without Adverse Effects. Int J Cancer (2016) 138 (7):1754-64. doi: 10.1002/ijc.29885

78. Stevens CW, Aravind S, Das S, Davis RL. Pharmacological Characterization of LPS and Opioid Interactions at the Toll-Like Receptor 4. Br J Pharmacol (2013) 168(6):1421-9. doi: 10.1111/bph.12028

79. Dai S, Zhang X, Zhang P, Zheng X, Pang Q. Fentanyl Inhibits Acute Myeloid Leukemia Differentiated Cells and Committed Progenitors via Opioid Receptor-Independent Suppression of Ras and STAT5 Pathways. Fundam Clin Pharmacol (2021) 35(1):174-83. doi: 10.1111/fcp.12581

80. Connolly JG, Tan KS, Mastrogiacomo B, Dycoco J, Caso R, Jones GD, et al. Intraoperative Opioid Exposure, Tumour Genomic Alterations, and Survival Differences in People With Lung Adenocarcinoma. Br J Anaesth (2021) 127 (1):75-84. doi: 10.1016/j.bja.2021.03.030

81. Antony J, Zanini E, Birtley JR, Gabra H, Recchi C. Emerging Roles for the GPI-Anchored Tumor Suppressor OPCML in Cancers. Cancer Gene Ther (2021) 28(1-2):18-26. doi: 10.1038/s41417-020-0187-6
82. Lane CM, Elde R, Loh HH, Lee NM. Regulation of an Opioid-Binding Protein in NG108-15 Cells Parallels Regulation of Delta-Opioid Receptors. Proc Natl Acad Sci USA (1992) 89(23):11234-8. doi: 10.1073/pnas.89.23.11234

83. Huang H, Liu B, Qu N, Zhang S, Bai X, Handley M, et al. Research Progress of Opioid Growth Factor in Immune-Related Diseases and Cancer Diseases. Int Immunopharmacol (2021) 99:107713. doi: 10.1016/j.intimp.2021.107713

84. McLaughlin PJ, Zagon IS. The Opioid Growth Factor-Opioid Growth Factor Receptor Axis: Homeostatic Regulator of Cell Proliferation and its Implications for Health and Disease. Biochem Pharmacol (2012) 84(6):74655. doi: 10.1016/j.bcp.2012.05.018

Conflict of Interest: MH has received research funding from CSL Behring, ZonMw, the Society of Cardiovasular Anesthesiologists (SCA) and the European Association of Cardiothoracic Anaesthesiology (EACTA); and has received compensation from Eurocept Pharmaceuticals BV and IDD for service as a consultant.

The remaining authors declare that the research was conducted in the absence of any commercial or financial relationships that could be construed as a potential conflict of interest.

Publisher's Note: All claims expressed in this article are solely those of the authors and do not necessarily represent those of their affiliated organizations, or those of the publisher, the editors and the reviewers. Any product that may be evaluated in this article, or claim that may be made by its manufacturer, is not guaranteed or endorsed by the publisher.

Copyright $\odot 2021$ Scroope, Singleton, Hollmann and Parat. This is an open-access article distributed under the terms of the Creative Commons Attribution License (CC BY). The use, distribution or reproduction in other forums is permitted, provided the original author(s) and the copyright owner(s) are credited and that the original publication in this journal is cited, in accordance with accepted academic practice. No use, distribution or reproduction is permitted which does not comply with these terms. 